\title{
CONTEMPORARY FORMS OF INTERNATIONAL MOVEMENT OF CAPITAL
}

\author{
Sanja Šovran*, Miroljub Hadžić \\ Singidunum University, \\ 32 Danijelova Street, Belgrade, Serbia
}

\begin{abstract}
:
International movement of capital is one of the most important forms of international economic cooperation and achievement of strategic goals of enterprises. It leads to international diversification of business activities, strengthening of competitive advantage, changes in economic structures, employment rates and economic stability of participating countries. The present research addresses the contemporary forms of international movement of capital, with an emphasis on the publicprivate partnerships and concessions. The creation of different forms of public-private partnerships (PPPs) in Serbia gained in importance in the early ' 90 s of the $20^{\text {th }}$ century. PPP implies joint activities within the framework of which the public and private sector pool resources, especially financial capital and expertise in order to meet the public needs of local, regional or national significance for adequate resource allocation. This type of partnership between the public and private sector has become an effective way towards a more rational use of limited resources and development of business entities from different sectors. The partnership of the public and private sector is particularly important in the construction and maintenance of transportation and other infrastructure facilities. Concessions represent a special form of public-private partnerships.
\end{abstract}

\section{Key words:}

international movement of capital, public-private partnership, concessions.

\section{INTRODUCTION}

The relevance of certain forms of international movement of capital has changed over time. The second half of the 80 s brought about significant changes leading to stagnation of loan capital, followed by the period of expansion of foreign direct investments. In the early 90 s of the $20^{\text {th }}$ century, a growing importance of interconnection between the public and private sector and emergence of dif- ferent forms of public-private partnerships could be observed. The role and importance of PPP was on the rise, as it proved to be an efficient way towards a more rational use of limited resources and development of business entities with different forms of ownership.

Pursuant to the Serbian Law on Public-Private Partnership and Concessions (Službeni glasnik RS, 2011, Article 4), public-private partnerships can be contractual, where their mutual relationships are regulated by a public-private partnership contract 
or institutionalized, when the relationship is based on the founder's or ownership shares or undertaking capital increase. Public-private partnerships are the novelty in the Serbian normative and economic practice, with the increase in demand for private funding, with the aim to build public infrastructure and investment in publicly-owned goods, goods in general use, as well as to provide high- quality services of general interest in the conditions of insufficient budget.

A concession is a special form of contractual public-private partnerships. Engaging the private sector in construction and maintenance of transport infrastructure in the form of concessions allows the release of budgetary funds and their use for diverse purposes. In addition, it brings the influx of capital, greater employment rates and transfer of new technologies.

This paper shall present contemporary forms of international movement of capital, their importance and development tendencies. Special emphasis shall be placed on capital investments through public-private partnerships and concessions. The paper shall give an overview of PPP and concession laws and legal regulations in the European Union and the Republic of Serbia, as well as development perspectives.

\section{INTERNATIONAL MOVEMENT OF CAPITAL}

International movement of capital means the transfer of real and financial assets between entities from one country to another one, without the counter-transference or counter-transference for a certain period of time, with the purpose of achieving certain economic and political interests of transfer participants (Unković, 2010, p. 127).

International movement of capital causes diversification of business activities, altering the economic structure, economic growth, balance of payments, employability, economic stability of certain countries, and strengthening of competitiveness and creation of global competitive products. To that end, the international movement of capital is one of the main generators and accelerators of globalization (Perović, 2005, p. 370).

The entities from developed countries have the greatest impact on the international movement of capital, as the main providers and users of capital. Entities from the developing countries generally appear as users of capital. Since the introduction of international movement of capital in the early $20^{\text {th }}$ century, many countries have based their economic development on the inflow of foreign capital.

Unlike other countries, those with higher efficiency in the national economy usually appear as investors. Surpluses are exported to other countries with the lower efficiency in the form of materialized capital supply.

International movements of capital are driven by various motives which are intertwined by certain factors, both in terms of supply and demand. Some motives for the international movement of capital are: market expansion and realization of greater profit, cheap labour, lower prices of raw materials and energy abroad, the desire for completion of the production process i.e. vertical integration of all or major phases of the final product, the psychological motive of prestige etc.

\section{Forms of international movement of capital}

The capital between the countries circulates in five basic forms (Stakić et al., 2015, p. 48), namely:

- Foreign direct investments (FDI);

- Foreign portfolio investments (capital market);

- Loans and credits;

- Investment and business operations in free zones;

- Investment of capital in the form of publicprivate partnerships.

The importance of certain forms of the international movement of capital has changed over time. 
The growing role of foreign direct investments, as a form of global economy financing, started to emerge in the period after World War II, to become particularly intensified in the last decade of the $20^{\text {th }}$ century (Stojadinović Janković, 2013, p. 40). In the period from the Second World War up to the 80 s of the $20^{\text {th }}$ century, loans had the primary role in the overall international movement of capital and financing of the world economy, particularly in developing countries.

Changes were to start in the second half of the 80 s, when after the culmination of debt crisis, stagnation was recored in the movement of the loan capital. Private capital ceased to flow into the developing countries in the form of loans, as the private sector refrained from any new crediting of the developing countries, except in the form of direct investments. Actually, it was the period from the 80 s and especially from the 90 s that turned out to be a period of expansion of the foreign direct investments (Stojadinović Janković, 2013, p. 36). It is noteworthy that at the beginning of the $20^{\text {th }}$ century, in addition to the non-banking sector, foreign investments were particularly important in the era of transition and privatization (Hadžić, 2013, p. 14).

Foreign direct investment is a form of investment in the company i.e. any form of financing of a certain company, in which the investor (the financier) acquires the ownership control over it (minimum $10 \%$ of the capital). Direct investments or foreign investments exist when a resident from one country (the exporting country, local government) invests in an entity of the resident from another country (the host country, receptive country or receiving country) with the aim to provide a longterm interest in that company (enterprise invested by the invested company (OECD, 1999, pp. 7-8).

Direct investments provide the investor a lasting interest and certain degree of control over the company he/she invests in (Stanković, 2013, p. 287). There are different forms of funding through foreign direct investments, namely: through Greenfield or Brownfield investments, joint ventures and international mergers and acquisitions (Petrović, 2002, p. 14)
The development of financial markets and financial instruments carries certain risk that the investors would attempt to diversify in portfolio investments. Portfolio investments are treated as a purchase of securities to a level that does not give the right of control over the entities in which the investment was made. They are in high demand by health insurance funds, pension funds and mutual funds.

In case of portfolio investments, there is no control over the operations of a company in which the investment is made, but the owner of securities gains profit in the amount of interest on the capital invested in securities. These investments imply international diversification, carrying a high level of currency risk i.e. foreign exchange risk (Perović, 2005, p. 371).

Purchase of foreign securities allows the presence on various financial markets and creates greater opportunity for risk diversification. Thus, this type of investment has become attractive for the investors who want a safe investment by achieving relatively high profits.

The international movement of loan capital is financial intermediation in the realization of financial surpluses of one sector towards financing of deficit in other sectors. Development of financial market and economy of developed countries contributed to diversification of methods and instruments of financial intermediation. At the beginning, it was in the form of classical loans, and later on, in the form of borrowing long-term capital through the issuance of bonds. Thus, the corporate sector, using a variety of financial instruments, relocates financial surpluses and deficits directly or through minimum intervention of the banking sector (Kovač, 2002).

Over the last twenty years, there has been a large expansion of the free zone concept, which uses a number of different models of a specific instrument of foreign trade operations, free of various charges imposed by the economic policy of the country. Despite the fact that there are many definitions of the free zone, the common aspect is 
that it is part of the territory of the country, specially fenced and marked areas in which economic and other activities are carried out under the guaranteed conditions and exemptions (Stakić et al., 2015, p. 127).

The World Bank defines export-processing zones as enclosed industrial areas, specializing in the production intended for export, providing for companies and user environment free of charge (World Bank, 1992).

The modern concept of free zones as specific development projects opened the possibility for countries and economies to create the most suitable form of free zones, i.e. the forms that suit best their specific characteristics and comparative advantages related to the political system, location, business and political environment, natural wealth etc. There are currently approximately 5000 different models of business operations worldwide under preferential conditions (Stakić et al., 2015, p. 128).

The investment of capital through public-private partnerships and concessions, as one of the contemporary forms of international movement of capital, shall be discussed in more detail in the following sections.

\section{CAPITAL INVESTMENT THROUGH PUBLIC-PRIVATE PARTNERSHIPS AND CONCESSIONS}

Linking the public and private sectors and the creation of different forms of public-private partnerships in Serbia is gaining in importance in the early 90 s of the $20^{\text {th }}$ century. Public-private partnership has become an effective way towards more rational use of limited resources and growth potentials. Public-private partnerships are intended for the improvement of business among entities with different property ownership forms-sectors.

There is no single, agreed definition of the concept of public-private partnerships, but in practice, in a broader sense, PPP involves the implementation of all known types of cooperation between public and private partners which, in many cases, leads to the establishment of joint ventures (Akitoby et al., 2007). In the narrow sense, PPP involves joint activities within the framework of which the public and private sectors pool resources and expertise in order to meet the public need through adequate allocation of resources, risks and rewards. Thus, the private sector, using different methods, can employ its resources and expertise in the provision of goods and services, traditionally provided by the public, i.e. state services (Skupština Republike Srbije, 2011, p. 4).

While establishing PPP, the public sector is expected to establish an adequate balance, i.e. the protection of rights and interests of citizens, and also to create conditions in which the private partners will be able to function effectively and efficiently (Vignjević Đorđević et al., 2011, p. 384).

\section{Types of public-private partnerships and concessions}

According to the European Commission Green Paper (EUR-lex, 2004), public-private partnerships can take the following forms:

- Contractual form of public-private partnerships involves a partnership based purely on contractual relations. Contractual form can have two basic models, namely: concession model of PPP in which the private partner charges the services to the end user, at the same time being under the control of the public partner and PFI (Private Finance Institute); model in which the private partner charges the delivered public services to the public partner in the form of a lease, which may be either fixed or vary over time, or possibly reduced, depending on the quality of delivered services.

- Institutional form of public-private partnership involves cooperation between the public and private partners achieved through a special business system which includes the establishment of a separate entity. This entity is owned jointly by private and public partners and the task of the partner is to en- 
sure the delivery of certain work or service for the benefit of the public interest. Such an entity can be established by taking over the existing public entity or by establishing a new joint entity, called Special Purpose Vehicle (SPV).

There is a whole spectrum of contractual forms of public-private partnerships, except for the two basic models, starting from the traditional state funding to traditional privatization. In international practice, there are approximately 20 models of PPPs, which differ in degree of involvement of the public and private sector in design, construction, maintenance, financing, operationalization, management and risk allocation in the provision of public services and/or construction of public infrastructure. Some of them are (Kačer et al., 2008) BOT (Build, Operate, Transfer); BTO (Build, Transfer, Operate); BOO (Build, Own, Operate); BBO (Buy, Build, Operate); PFI (Private Finance Initiative).

According to the Serbian Law on Public-Private Partnership and Concessions, (Službeni glasnik RS, 2011, Article 10), a concession is a legal relationship between the state, as a concession grantor, and national or foreign persons, as concessionaries, in which the state gives such persons the right to use natural resources or assets for general purposes determined by the law to be owned by the Republic of Serbia or to perform certain activities of general interest for a certain period of time and for a certain concession fee.

The main function of the concession, as a form of investment in a particular area of the economy, is to encourage faster development and thus boost the overall national development. Concessions are particularly significant when the investor is a foreign person, and such concession is treated as a form of foreign investment.

The most general model of concession is B.O.T. system (build-operate-transfer). Serbian legislation in this area is focused on opening the market for the entry of foreign capital to our country. Concessions may not be granted to a foreign person for the areas in which, according to the law governing foreign investments, a foreign person cannot be the founder of the entity (for example, the area of production and sales of arms), nor the area that is determined as the prohibited zone in accordance with the law.

\section{PPP AND CONCESSIONS - LEGAL REGULATION IN THE EUROPEAN UNION}

The concept of concessions dates back to the Roman Empire. Public-private partnership, as a concept of privatization of public infrastructure, dates back to the $18^{\text {th }}$ century. Governments of underdeveloped countries made concession arrangements with large companies, which was the most common form of concessions at that time. The creation of the European Union urged the legal regulation of areas which include concessions, free movement of goods and services, public procurement etc. These regulations shall become the corner stone for the development of new forms of public-private partnerships (Skupština Republike Srbije, 2011, p. 5).

During the $20 \mathrm{~s}$ of the $20^{\text {th }}$ century, the countries of Central and Eastern Europe had developed a complex legal framework of PPP. The basic laws (such as laws on local self-government or concessions) were necessary, but in order to create favourable legal and administrative environment, more was required. The technical aspects of engagement of private sector needed to be regulated: industrial laws and strategies, public procurement procedures, different forms of management over services, public assets, and particularly regulations governing local autonomy in the management of municipal property (Osborne, 2000).

Until 2014, there were no regulations directly specifying the implementation of PPP projects in Member States, but there were some guidelines and directives, and they constituted the basic legal framework that guided and encouraged the improvement of the legislation of the EU Member States, aiming at better regulation in the area of public-private partnership. The existing EU legal regulation in the area of public-private partnership includes important chapters of the European law (Skupština Republike Srbije, 2011, p. 5), namely: free movement of capital, the right of establishment and freedom to provide services, public 
procurement, intellectual property rights, company rights, competition rights, financial services, finance and accounting etc.

Previous legislation focused more on public procurement and concessions, but the development of public-private partnership required more complete legislation. In 2000, Commission interpretative communication on concessions under community law, regulating concessions in Member States, regulated the area of PPPs. More complex relations between the public and the private sector urged the institutions to continuously adopt new rules to meet the market demands (EUR-lex, 2000).

The further regulation of the European legislation was not made until 2014. The Official Journal of the European Union from February 2014 published three new directives in the area of public procurement (Stakić et al., 2015, p. 18), namely:

- Directive 2014/23/EU of the European Parliament and Council on the award of concession contracts;

- Directive 2014/24/EU of the European Parliament and Council on public procurement (Utilities Directive) and repealing Directive 2004/18/EC; and

- Directive 2014/25/EU of the European Parliament and Council on procurement by entities operating in water, energy, transport and postal services sectors and repealing Directive 2004/17/EC.

\section{PPP AND CONCESSIONS-LEGAL REGULATION IN SERBIA}

Not until the adoption of the Law on Publicprivate Partnership and Concessions, this area was regulated at the national level by the Law on Concessions (2003), while at the local level, private sector investments in the infrastructure were carried out in accordance with the Law on Public Utilities (1997), providing the opportunity to entrust another entity the performance of communal activities. Unlike concessions which are not a novelty in the Serbian economy and normative practice, it was the Law on Public-Private Partnership and
Concessions (2011) that introduced the publicprivate partnership in the legal system.

The aforementioned law states that the publicprivate partnership project is a project prepared, proposed, approved and implemented based on one of the public-private partnership models. It consists of a series of interconnected activities taking place in a specific sequence for the purpose of achieving the identified objectives within the specified time period and the financial framework which, in compliance with this law, has been approved as a public-private partnership project, with or without concession elements (Službeni glasnik RS, 2011, Article 4).

Mutual relationship is regulated by a publicprivate partnership contract, where a public body may be a state body or an institution or other direct and indirect users of budgetary funds, then a public company and legal entity performing the activity of general interest (mainly state-owned).

In addition to the Law on Public-Private Partnerships and Concessions, realization of PPPs also largely relies on the provision of the following acts (Stakić et al., 2015, p. 18), namely: Law on Public Procurement (2015), Law on Communal Activities (2011), Law on Public Enterprises (2016), Law on Public Property (2014), Law on Local self-Government (2014), Law on Local-Self Government Financing (2013), Law on Regional Development (2010), Law on Foreign Investments (2014) and Law on Energy (2014). In addition to these laws, regulations of systematic character also remain valid, such as the Law on Companies (2015), Law on Profit Tax (2015), Law on Labour (2014), environmental legislation etc.

\section{THE IMPORTANCE OF FOREIGN INVESTMENTS THROUGH PPP AND CONCESSIONS}

Public-private partnership model results in the creation of added value for the public and private partner. Private partner gains the planned profit margin, reduces business risk and costs of 
sub-investment, while the public partner achieves higher quality of public services, reduces public spending and has the possibility to provide more public services within a shorter period of time and overcome debt restrictions more easily (McCreevy, 2005 , p. 2). Gaining additional value is the result of competition in the process of production of public goods or provision of public services. The ultimate goal of public-private partnerships is to provide better, more efficient and effective public services and to increase the prosperity of the population (Bojović, 2006, p. 311).

The partnership of public and private sector is particularly important in the construction and maintenance of transport infrastructure and for other types of infrastructure (water supply, communications). Engaging the private sector in the construction and maintenance of transport infrastructure in the form of concessions allows the release of budgetary funds and their use for other purposes (Vukmir et al., 1999). In addition, the positive effects of concessions are the influx of capital, higher employment and transfers of new technologies.

The Law on Public-Private Partnership and Concessions allowed the participation of new concessionaires in bidding and opened the door for the inflow of foreign capital in activities which may be the subject of the concession. Accordingly, the legal and conceptual notion frame of concession provides legal security to the investor, which is of great importance for development of the Republic of Serbia, especially as regards the use of forests and forest land, construction of energy facilities and transport infrastructure, and other areas regulated by the law.

Serbia's economic development requires taking serious actions towards the improvement of transport infrastructure. It is necessary to put in the function the existing road network and to build new highways to ensure safe, quality and fast traffic. The lack of funds can be compensated, among other things, by granting concessions for public utilities (Knežević, 2010, p. 91).
Granting concessions may also cause certain issues, as shown in practice in our country and globally (Dimitrijević, 2008, p. 317). One of many issues related to concessions in the area of road infrastructure is the issue of their privatization. In the public road construction funded by the Government, tolls generally do not depend on the cost of construction. However, in the case of concessions, the concession grantor has the right to collect tolls and other revenues for its duration (Knežević, 2010, p. 100).

\section{PERSPECTIVES AND POTENTIALS OF PPPS AND CONCESSIONS IN SERBIA}

Public-private partnership in Serbia is mostly exercised in the form of institutionalized (mixed) PPP for utility services or in the form of contractual PPP, where the private investor performs the utility services. Establishment of PPP in Serbia was driven by a combination of factors (Ilić et al., 2011, p. 510), as follows:

- search for private funding to complement public budgets;

- desire to use know-how and operational skills of the private sector;

- structural changes in the role of local government, which is increasingly becoming an organizer, regulator and controller and less direct operator.

In recent years, the result of cooperation between the public and the private sector has been characterized by development of infrastructure and infrastructure management, intended to carry out a series of economic activities. Public-private partnerships offer a wide range of options, from those in which the private sector is minimally involved to those in which the private sector significantly participates in project management, such as reconstruction of infrastructure, investments in infrastructure, concessions and B.O.T. contracts (Gulija, 2004). 


\section{CONCLUSIONS}

The international movement of capital is driven by various motives that are intertwined by certain factors both in terms of supply and demand. In practice, public-private partnership involves implementation of all well-known types of cooperation between public and private partners which, in many cases, leads to the establishment of joint ventures. Thus, the private sector employs its resources and expertise in the provision of goods and services, traditionally provided by public, i.e. state services. While establishing PPP, the public sector is expected to establish the appropriate balance, i.e. the protection of rights and interests of citizens, and also to create conditions in which the private partners will be able to function effectively and efficiently.

Besides the tow basic forms, contractual and institutionalized, there are approximately twenty different models in PPP international practice, differing in the degree of involvement of the public and private sector in all stages of provision of public services and/or construction of public infrastructure. The main function of concession, as a form of investment in a particular area of the economy, is to encourage faster development, and boost the overall national income. Concessions are particularly significant when the investor is a foreign person, and such concessions are treated as foreign investments.

Until 2014, there were no regulations that could directly control the implementation of PPP projects in the EU Member States, but there were some guidelines and directives, and they constituted the basic legal framework that guided and encouraged the improvement of the legislation of the EU Member States, aiming at better regulation in the area of public-private partnerships. Until the adoption of the Law on Public-Private Partnership and Concessions in Serbia, this area was regulated at the national level by the Law on Concessions (the first law was adopted in 1990), while the governing law at the local level was the Law on Public Utilities.
The public-private partnership model results in the creation of added value both for the public and private partner. Private partner gains the planned profit margin, reduces business risk and costs of sub-investment, while the public partner achieves higher quality of public services, reduces public spending and has the possibility to provide more public services within a shorter period of time and overcome debt restrictions more easily. The result of cooperation between the public and private sector is characterized by development of infrastructure and infrastructure management, intended to carry out a number of economic activities.

\section{REFERENCES}

Akitoby, B., Hemming, R., \& Schwartz, G. (2007). Public Investment and Public-private partnerships. Washington, DC: International Monetary Fund.

Bojović, V. (2006). Public Private Partnerships as a Last Resort for Traditional Public Procurement. Panoeconomicus, 3, 299-311.

Dimitrijević, D. (2008). Koncesiona prava u međunarodnoj i domaćoj praksi. Pravni život, 522(12), 317-332. In Serbian.

EUR-lex. (2000). Official Journal of the European Communities, C 121. Retrieved October 30, 2015, from http://eur-lex.europa.eu/legal-content/EN/TXT/?u $\mathrm{ri}=\mathrm{OJ} \% 3 \mathrm{AC} \% 3 \mathrm{~A} 2016 \% 3 \mathrm{~A} 121 \% 3 \mathrm{ATOC}$

EUR-lex. (2004). Green Paper on public-private partnerships and Community law on public contracts and concessions. Retrieved October 30, 2015, from http://eur-lex.europa.eu/legal-content/EN/ TXT/?uri=URISERV:122012

Gulija, B. (2004). Javno-privatno partnerstvo. Euroscope, 13(73), 1-4. Retrieved October 30, 2015, from http://www.javno-privatno-partnerstvo.eu/JPP/JPP. pdf. In Croatian.

Hadžić, M. (2013). Bankarstvo. Beograd: Univerzitet Singidunum. In Serbian.

Ilić, S., \& Pašić, V. (2011). Perspektiva javno privatnog partnerstva u Srbiji. Operacioni menadžment u funkciji održivog ekonomskog rasta i razvoja Srbije 2011-2020: zbornik radova / VIII skup privrednika i naučnika - SPIN'11, Beograd, 01-02. novembar 2011, 505-511. In Serbian.

Kačer, H., Kružić, D., \& Perković, A. (2008). Javnoprivatno partnerstvo: Atraktivnost dbfoot modela. Zbornik radova Pravnog fakulteta u Splitu, god. 45, 3/2008, 603-640. In Croatian. 
Knežević, M. (2010). Značaj koncesija za strana ulaganja u Republici Srbiji. Ekonomski horizonti, 12(1), 89-102. In Serbian.

Kovač, O. (2002). Međunarodne finansije. Beograd: Ekonomski fakultet.

McCreevy, C. (2005). Public-Private Partnerships-Options to ensure effective competition, PPP Global Summit. Copenhagen: Forum on Public-Private Partnership, p. 1-5.

OECD. (1999). OECD benchmark definition of foreign direct investment. Paris: Organisation for Economic Co-operation and Development.

Osborne, S.P. (2000). Public-Private Partnerships: Theory and practice in international perspective. New York: Routledge.

Perović, J. (2005). Međunarodno kretanje kapitala kao generator i akcelerator globalizacije. Ekonomija/ Economics, 12(2), 369-383. In Serbian.

Petrović, J. (2002). Pravni aspekti stranih ulaganja, Pravo i privreda, 1-4/2002.

Skupština Republike Srbije. (2011). Javno-privatno partnerstvo i koncesije, Z-26/10. Beograd: Skupština Republike Srbije.

Službeni glasnik RS. (2011). Zakon o javno-privatnom partnerstvu i koncesijama. Službeni glasnik RS br. 88/2011. In Serbian.
Stakić, B., Vasić, D., \& Curković, V. (2015). Ulaganje kapitala putem javno-privatnog partnerstva $i$ koncesija. Beograd: Fakultet za polovne studije i pravo. In Serbian.

Stanković, B. (2013). Javno-privatno partnerstvo I koncesije, kao posebni oblici stranih ulaganja u Srbiji. Economy and Market Communication Review, 3(2), 285-298. doi:10.7251/EMC1302285S

Stojadinović Jovanović, S. (2013). Foreign Direct Investments as a Form of Financing Global Economy. Bankarstvo, 1/2013, 34-57. Retrieved October 30, 2015, from http://www.ubs-asb.com/Portals/0/Casopis/2013/1/UBS-Bankarstvo-1-2013-StojadinovicJovanovic.pdf. In Serbian.

Unković, M. (2010). Međunarodna ekonomija. Beograd: Univerzitet Singidunum. In Serbian.

Vignjević Đorđević, N., \& Radević, B. (2011). Public management and quality of corporate governance: international and domestic experiences. Proceedings. Vol. 3/ 2nd International Conference Law, Economy and management in Modern Ambience - Lemima 2011, Belgrade, Serbia, 12-15. April 2011, pp. 383-389.

Vukmir, B., \& Skendrović, V. (1999). Koncesije i ugovaranje BOT projekata. Zagreb: Hrvatski savez građevinskih inženjera. In Croatian.

World Bank. (1992). Export Processing Zones, Policy and Research Series Paper 20. Washington, DC: Industry and Energy Department.

\section{SAVREMENI OBLICI MEĐUNARODNOG KRETANJA KAPITALA}

\section{Rezime:}

Međunarodno kretanje kapitala predstavlja jedan od najznačajnijih oblika međunarodne ekonomske saradnje i ostvarivanja strateških ciljeva privrednih društava. Na taj način dolazi do međunarodne diversifikacije poslovnih aktivnosti, jačanja konkurentske prednosti, promene privrednih struktura, stopa zaposlenosti i privredne stabilnosti zemalja-učesnica. Savremeni oblici međunarodnog kretanja kapitala predstavljaju predmet istraživanja ovog rada, sa posebnim osvrtom na javno-privatna partnerstva i koncesije. Stvaranje različitih oblika javno-privatnog partnerstva (JPP) u Srbiji dobija na značaju tek početkom 90-tih godina prošlog veka. JPP podrazumeva zajedničke poslove u sklopu kojih javni i privatni sektori udružuju resurse, posebno finansijski kapital i stručna znanja kako bi, kroz adekvatnu raspodelu sredstava, rizika i nagrada, zadovoljili potrebe od lokalnog, regionalnog ili nacionalnog značaja. Ovakav vid partnerstva javnog i privatnog sektora postaje efikasan način za racionalnije korišćenje ograničenih resursa i unapređenje poslovanja subjekata iz različitih sektora. Partnerstvo javnog i privatnog sektora ima posebnu ulogu u procesu izgradnje i održavanja saobraćajne, ali i drugih objekata infrastrukture. Koncesija predstavlja poseban vid javno-privatnog partnerstva.

\section{Ključne reči:}

međunarodno kretanje kapitala, javno-privatna partnerstva, koncesije. 